\title{
Determination of Protein-Bound lodine (PBI) in Sera from Patients with Various Thyroid Diseases by Neutron Activation Analysis
}

\author{
Satoshi Hamada, Kanji Torizuka, Ken Hamamoto, Jun Nakagawa, Toru Mori, \\ Rikushi Morita, Tsuyoshi Nakagawa, Junji Konishi, Tadashi Miyake, and \\ Masaichi FUKASE \\ Second Division of Internal Medicine and Central Clinical Radioisotope Division, \\ Kyoto University Medical School, Kyoto \\ Received October 24, 1966
}

\begin{abstract}
Activation analysis was performed for measuring protein-bound iodine(PBI)in serum and trace amounts of iodine. The samples of human serum were passed through an ion-exchange column, and to which were added small amounts of ${ }^{131} \mathrm{I}$ for recovery check. Acid digestion was then carried out by adding chromium trioxide and sulfuric acid, and distillation followed after adding phosphorous acid and hydrogen peroxide. The iodine evolved rvas trapped in potassium hydroxide. An aliquot of the distillate was placed in a polyethylene ampoule, and was irradiated in the pile at a thermal neutron flux of $4 \times 10^{12} \mathrm{n} / \mathrm{cm}^{2} / \mathrm{sec}$ for either 15 or 30 minutes. The induced ${ }^{128} \mathrm{I}$ with added carriers was oxidized with Laundry beach, reduced with $\mathrm{Na}_{2} \mathrm{~S}_{2} \mathrm{O}_{5}$, and then extracted with carbon tetrachloride after adding sodium nitrite. The carbon tetrachloride laver was washed with dil- $\mathrm{H}_{2} \mathrm{SO}_{4}$ and distilled water.

Then ${ }^{128} \mathrm{I}$ reas reduced to iodide with $\mathrm{Na}_{2} \mathrm{~S}_{2} \mathrm{O}_{5}$, precipitated with silver nitrate, and assayed in a multi-channel pulse height analyzer and a Geiger-Müller counter. This post-irradiation chemistry could be performed in approximately 30 minutes. The gamma ray spectrum and decay curve indicated the absence of nuclides other than ${ }^{128} \mathrm{I}$ and ${ }^{131} \mathrm{I}$. PBI was determined on sera obtained from patients with thyroid diseases and normal subjects, and the values obtained were nearly the same as those by the chemical method. The duplicate determinations indicated good reproducibility. By this procedure, we could measure $2.9 \times 10^{-9} \mathrm{~g}$ of iodine.
\end{abstract}

\section{Introduction}

Neutron activation analysis is a very sensitive method for the determination of iodine, and makes it possible to measure such a minute amount of iodine as $10^{-10} \mathrm{~g}^{1), 3), 4)}$. Further, the ${ }^{125} \mathrm{I}$ induced on thermal neutron irradiation has the half-life of 25 minutes, and indicates the photopeak of $0.45 \mathrm{MeV}$. These properties give a very high specificity to the determination of iodine by this method ${ }^{2)}$. Recently, the comparisons between activation analysis and colorimetry in measuring proteinbound iodine (PBI) were reported ${ }^{4), 6)}$. This paper is concerned with the determination of PBI in patients with various thyroid diseases by activation analysis, and with comparison between the values obtained and those by the colorimetric procedure.

\section{Experimental}

\subsection{Pre-irradiation Chemistry}

Serum samples were freed from inorganic iodide and other obstructive contaminations by passing them through an ion-exchange resin column $\left.{ }^{6}\right)$. Equal parts of Dowex $1 \times 8(50-100$ mesh) in the acetate phase and of Dowex 50W $\times 8(50-100$ mesh $)$ in the $\mathrm{NH}_{4}{ }^{+}$phase were mixed, and packed into a $1 \times 10 \mathrm{~cm}$ column by tamping with a glass stick. The column was then treated with $50 \mathrm{ml}$ of $10^{\circ} \%$ ammonium acetate, and washed with $25 \mathrm{~m} l$ of distilled demineralized water.

A $2 \mathrm{~m} l$ serum sample was pipetted onto the resin column, and passed at the flow rate of $4 \sim 5 \mathrm{~m} l / \mathrm{min}$. The effluent was directly collected in the distillation flask containing minute amount of carrier-free $\mathrm{Na}^{131} \mathrm{I}$ for recovery check. Immediately after the serum had drained off, $20 \mathrm{~m} l$ of distilled demineralized water was added to wash it off. At this stage, the recovery of thyroxine was $92.21 \%$ on the ave- 
rage $( \pm 0.37 \%$ relative standard deviation, 5 determinations). These values were obtained by using serum to which ${ }^{131}$ I-thyroxine* was bound in vitro.

The eluate was subjected to acid digestion with $3 \mathrm{ml}$ of $50 \% \mathrm{CrO}_{3}$ and $15 \mathrm{ml}$ of conc. $\mathrm{H}_{2} \mathrm{SO}_{4}{ }^{5)}$. Distillation followed after adding 5 $\mathrm{m} l$ of $50 \% \mathrm{H}_{3} \mathrm{PO}_{3}$ and $0.25 \mathrm{ml}$ of $30 \% \mathrm{H}_{2} \mathrm{O}_{2}{ }^{5)}$, and the iodine evolved was trapped in $0.5 \mathrm{ml}$ of $1 \mathrm{~N} \mathrm{KOH}$. The distillate was concentrated to $1.0 \mathrm{~m} l$ with evaporation at $100^{\circ} \mathrm{C}$, and the $0.5 \mathrm{ml}$ aliquot was transfered to a polyethylene ampoule, and evaporated to dryness at 60 to $70 \mathrm{C}$.

\subsection{Standard}

Potassium iodide dissolved in $\mathrm{KOH}$ was used as iodide standards after adding carrierfree $\mathrm{Na}^{131} \mathrm{I}$ for recovery check. The induced ${ }^{125} I$ in this solution was found to be easily extractable with water.

\subsection{Irradiation}

The samples were irradiated for 15 minutes at a flux of $4 \times 10^{12}$ thermal neutrons $/ \mathrm{cm}^{2} \cdot \mathrm{sec}$ in the pile at the Research Reactor Institute of Kyoto University. The iodide standard was placed with samples in each of two tiers in a pneumatic tube, because there appeared to be a significant neutron flux density variation between two tiers.

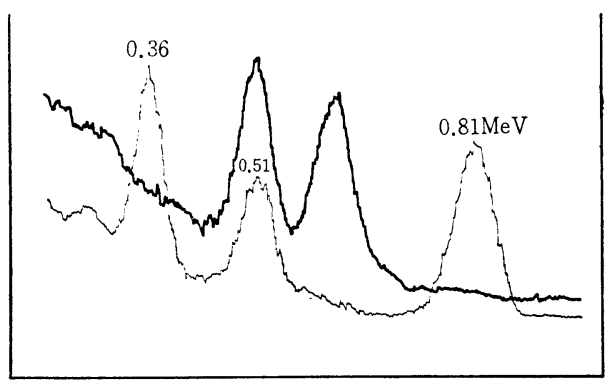

Firs. I A camma-ray spectrum of a sample of no post-iradiation chemistry.

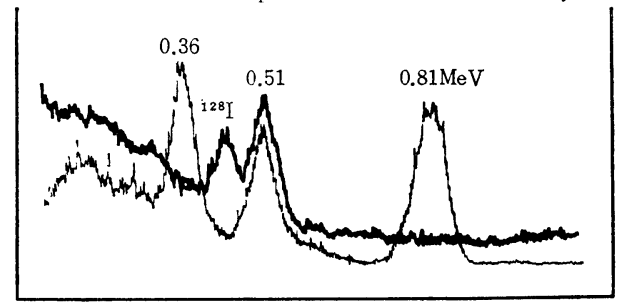

Fig. 1 (B) Gamma-ray spectrum of a standard of no post-irradiation chemistry.
Gamma-ray spectra immediately after the irradiation are shown in Fig. 1 for a sample (A) and an iodide standard (B) with no postirradiation chemistry. The induced ${ }^{123} \mathbf{I}$ peak was seen only in the iodide standard.

2.4 Post-irradiation Chemistry

The irradiated samples were immediately subjected to post-irradiation chemistry, because the half-life of neutron induced ${ }^{128} \mathbf{I}$ is only 25 minutes.

Selective oxidation and reduction of iodine were carried out by the method of Duce and Winchester ${ }^{3)}$. The sample was extracted three times with distilled water, and transferred to a $100 \mathrm{ml}$ Erlenmeyer flask containing $20 \mathrm{mg} \mathrm{KI}$, 1 drop of phenolphthalein and 4 drops of $12 \mathrm{M}$ $\mathrm{NaOH}$ in $5 \mathrm{ml} \mathrm{H}_{2} \mathrm{O}$. The iodide was, at first, oxidized to $\mathrm{IO}_{4}^{-}$by adding 5 drops of $5 \%$ $\mathrm{NaClO}$, and then reduced to $\mathrm{I}^{-}$by adding 6 drops of $16 \mathrm{M} \mathrm{HNO}_{3}$ and $5 \sim 8$ drops of $0.5 \mathrm{M}$ $\mathrm{Na}_{2} \mathrm{~S}_{2} \mathrm{O}_{5}$. The solution was made basic to phenolphthalein with $6 \mathrm{M} \mathrm{NaOH}$, followed by adding $1.0 \mathrm{~m} l$ of glacial acetic acid. After adding 5 8 drops of $1 M \mathrm{NaNO}_{2}$, it was extracted twice with $10 \mathrm{ml}$ of $\mathrm{CCl}_{4}$. The $\mathrm{CCl}_{4}$ layer was given two washes with $25 \mathrm{ml}$ of dil. $\mathrm{H}_{2} \mathrm{SO}_{4}$ and $25 \mathrm{ml}$ of $\mathrm{H}_{2} \mathrm{O}$, and the iodine was extracted to the aqueous layer as iodide by shaking with aqueous $\mathrm{S}_{2} \mathrm{O}_{5}^{--}$. The silver iodide was precipitated by adding $5 \mathrm{ml}$ of $0.1 \mathrm{~N} \mathrm{AgNO}_{3}$ in 2 to $3 \mathrm{ml}$ of $16 M \mathrm{HNO}_{3}$, filtrated on filter paper, and washed with water, ethanol and ethyl ether. All the chemical procedures could be performed in approximately $25 \sim 30$ minutes.

2.5 Counting and Calculation

The samples were assayed in a multichannel pulse height analyzer and a Geiger-Müller counter. Gamma-ray spectra (Fig. 2(A), (B)) revealed that the nuclides other than ${ }^{128} \mathbf{I}$ and ${ }^{131}$ I were eliminated by the post-irradiation chemistry. Decay curve measured by a GeigerMüller counter (Fig. 3) showed nearly a straight line (half-life of 25 minutes) corresponding to theoretical half-life of ${ }^{126} \mathrm{I}$. After the initial decay, decline in the counting rate slowed, indicating ${ }^{131} \mathrm{I}$ added for recovery check.

* Abbott Laboratories 


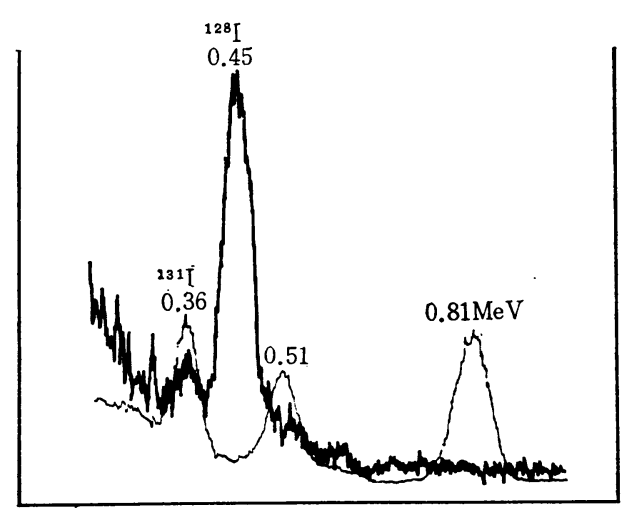

Fig. 2 (A) Gamma-ray spectrum of a sample of post-irradiation chemistry.

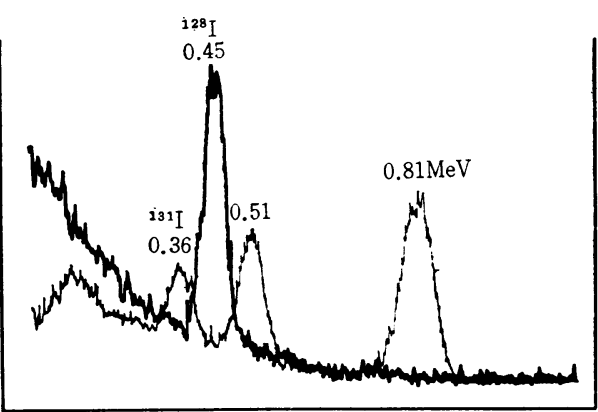

Fig. 2 (B) Gamma-ray spectrum of a standard of post-irradiation chemistry.

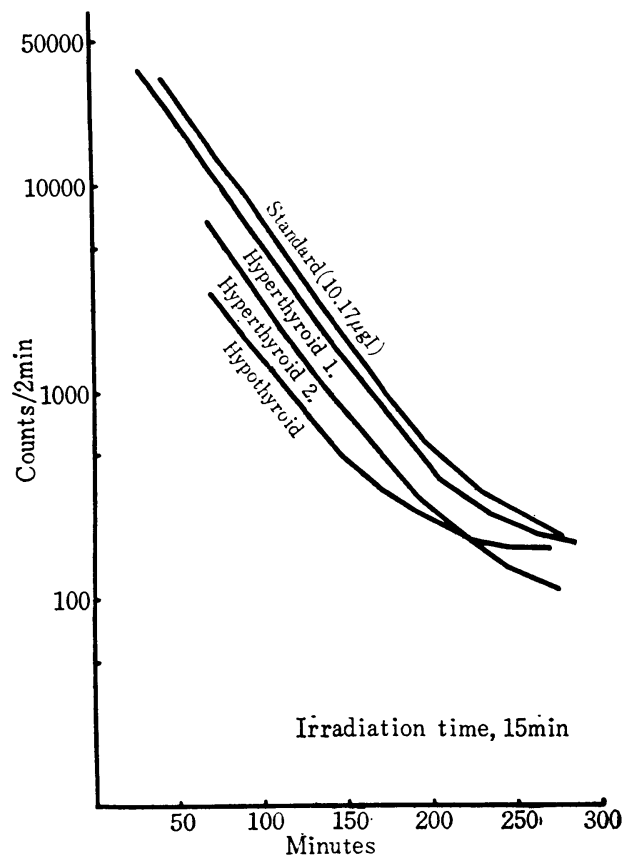

Fig. 3 Determination of PBI by activation analysis. Decay curve of ${ }^{\mathbf{1 2 8}} \mathrm{I}$.
The counting rates used for calculations were read from graphs of the decay curves, and corrected by the following formula. The chemical yields for samples and standards were estimated by counting radioactivity of ${ }^{131} \mathrm{I}$ after decay out of ${ }^{128} \mathrm{I}$ at $0.36 \mathrm{MeV}$ photopeak of ${ }^{131} \mathrm{I}$ with a single channel pulse height analyzer. They were in general $70 \sim 80 \%$.

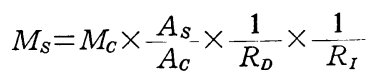

where $M_{S}=$ Mass of iodine in the sample

$M_{C}=$ Mass of iodine in the standard with correction of ${ }^{131} \mathbf{I}$

$A_{s}=$ Activity of the sample

$A_{C}=$ Activity of the standard

$R_{D}=$ Recovery of ${ }^{131} I$ in distillation and extraction

$R_{I}=$ Recovery of ${ }^{131}$ I-thyroxine bound to serum in passage through ionexchange resin $(92.21 \pm 0.37 \%)$

\section{Results}

Various amounts of iodide standards were determined to evaluate the precision of this method. By the correction of ${ }^{131} \mathbf{I}$, good results were obtained as shown in Table 1.

Table 1 Determination of iodine by activation analysis

KI Standard

\begin{tabular}{c|c}
\hline KI & Activ. anal. \\
\hline 0.1 & 0.0997 \\
\hline 0.05 & 0.0551 \\
\hline 0.025 & 0.0251 \\
\hline
\end{tabular}

Duplicate determinations of PBI were carried out on sera from a hyperthyroid, an euthyroid and a hypothyroid. The data, as shown in Table 2, indicated good reproducibility at various levels of PBI.

Table 2 Duplicate determination of PBI

\begin{tabular}{c|c|c}
\hline & 1 st Determ. & 2 nd Determ. \\
\hline Hyperthyroid & 11.6 & 9.7 \\
\hline Euthyroid & 5.6 & 4.5 \\
\hline Hypothyroid & 2.3 & 1.5 \\
\hline \multicolumn{2}{c}{$(\mu \mathrm{g} / 100 \mathrm{ml})$}
\end{tabular}


The PBI was determined on 10 human sera from patients with various thyroid diseases by both the activation analysis and the chemical method. The comparison between the two methods is presented graphically in Fig. 4. The values obtained by the two methods appeared to be nearly consistent with each other.

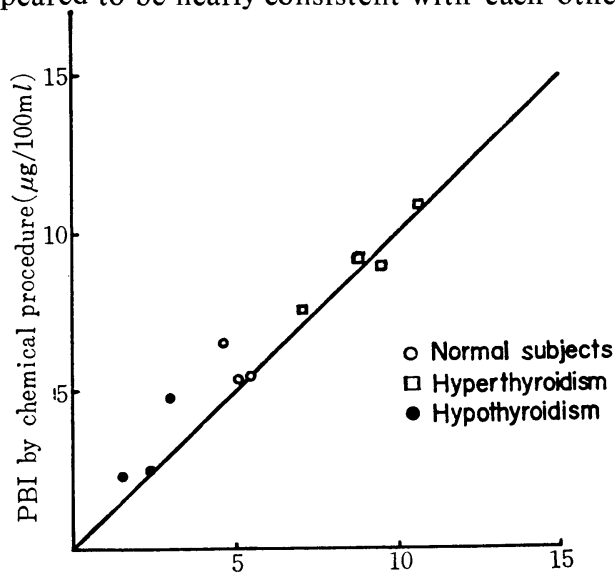

PBI by activation analysis procedure $(\mu \mathrm{g} / 100 \mathrm{~m} l)$

Fig. 4 Comparison of activation analysis procedure and chemical procedure for PBI

\section{Discussion}

There are various chemical methods in determining PBI, but the principal sources of the error consist in the difficulty of the colorimetry of iodine. Kellershohn, et al. ${ }^{4)}$ applied thermal neutron activation analysis in place of the colorimetric determination of iodine in the chemical method. They ${ }^{4}$ described two methods in estimating the induced ${ }^{128} \mathrm{I}$ : gammaray spectrometry and $\beta$-counting. Although gamma-ray spectrometry permitted coexistence of some contaminants, it is less sensitive and it takes much more time to measure than $\beta$-counting. Kellershohn, et al. ${ }^{4}$ obtained somewhat lower values of PBI with better accuracy than those by the colorimetric determination. Smith, et al. ${ }^{6)}$ determined PBI by gamma-ray spectrometry using "spectrum stripping" to eliminate interference from remaining radioactive contaminants after incomplete separation of iodine. They obtained systematically higher values of PBI than the Barker's chemical method, and suggested the presence of another iodine component such as iodotyro- sines. However, it might be impossible to exclude the possibility of contamination by their indirect method.

In an attempt to determine PBI by Kellershohn's method, the authors were confronted with two problems: considerably lower yield of iodine and unremovability of radioactive contaminants. The lower yield may be explained as follows: although the iodine in the samples is irradiated in the form of iodide, some part of the iodide must be oxidized to various oxides during the irradiation. Therefore, only the part which remained as iodide would be extracted with $\mathrm{CCl}_{4}$ after its oxidation with $\mathrm{HNO}_{2}$. Should this be the case, selective oxidation and reduction by Duce and Winchester $^{3)}$ would be a very reasonable method. But, hydroxylamine which was used in their method was known to reduce the yield of iodine by reduction to iodide. Therefore, two washes with dil. $\mathrm{H}_{2} \mathrm{SO}_{4}$ and water were given instead of hydroxylamine.

These procedures resulted consistently in a high yield and the removal of radioactive contaminants other than iodine.

The PBI values obtained by this method were nearly consistent with those by the colorimetric method.5) These results did not support Smith, et al.'s suggestion ${ }^{6)}$ that there might be any iodine components in serum which could not be measured by the chemical method.

\section{Summary}

Protein-bound iodine was determined by activation analysis on sera from patients with various thyroid diseases. The serum, passed through an ion-exchange resin column, was subjected to acid digestion and distillation, and the iodine evolved was trapped in potassium hydroxide, which was irradiated for 15 minutes in a flux of $4 \times 10^{12}$ thermal neutrons/ $\mathrm{cm}^{2} \cdot \mathrm{sec}$. The induced ${ }^{129} \mathrm{I}$, after selective oxidation and reduction, was extracted with carbon tetrachloride, and precipitated with silver nitrate. This procedure resulted in a high yield of iodine and elimination of contaminats other than iodine. The protein-bound iodine values obtained were nearly the same 
as those by the colorimetric method.

\section{Acknowledgements}

This study was carried out at the Research Reactor Institute of Kyoto University. The authors are greatly indebted to Associate Professor S. Iwata and Associate Professor G. Yoshii of the Research Reactor Institute of Kyoto University, for their advices during this investigation.

\section{References}

1) Bowen, H.J.: Biochem. J., 73, 381-84(1959)

2) Dimitriadou, A., P. C. R. Turner and R. Fraser: Nature, 197, 446-49(1963)

3) Duce, R.A. and J.W. Winchester: Radiochim. Acta, 4, 100-04(1965)

4) Kellershohn, C., D.Comar et C. Le Poec: Intern. J. Appl. Rad. Isot., 12, 87-103(1961)

5) Koshiyama, K.: Jap. Arch. Int. Med. (Japanese), 9, 381-92(1962)

6) Smith, E. M., J.M. Mozley and H. N. Wagner, Jr.: J. Nucl. Med., 5, 828-39(1964)

要

旨

\title{
諸種の甲状腺疾患々者のタンパク結合ヨウ素(PBI)の放射化分析による測定
}

\author{
浜田 哲, 鳥塚莞爾, 浜本 研, 中川 潤, 森徹, \\ 森田陸司, 中川 毅, 小西淳二, 三宅 儀, 深瀬政市 \\ 京都大学医学部内科第 2 講座扣よび中央放射線部
}

\begin{abstract}
諸種の甲状腺疾患々者のタンパク結合ヨウ素を放射化分析により測定した。イオン交換樹脂カ ラムを通過させた血清を，酸水解および蒸留を行ない，生じたヨウ素分子を水酸化カリウムに捕捉

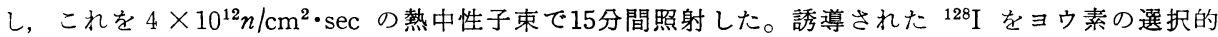
酸化および還元を行なったのち，四塩化炭素で抽出し，硝酸銀で沈殿せしめ心。この方法によりヨ ウ素の高収率を得，またヨウ素以外の放射性核種を除去し得た。本法により測定されたタンパク結 合ヨウ菜の值は，比色法による值とほほ同一であった。
\end{abstract}

